\title{
FRANZ SCHNEEWEISS: A '48er IN NEW BRUNSWICK
}

\author{
BY F. GUNTHER EYCK
}

F. Gunther Eyck, Lecturer in the Department of History of the Rutgers College of Arts and Sciences, is very much interested in nineteenth century European history and especially in liberalism. He has made a study of a collection of papers on and by Franz Schneeweiss, which was turned over to the Library in 1955 by Miss Catherine M. Schneeweiss. The results of his study of these interesting papers of a family connected with Rutgers University since the mid-nineteenth century have been condensed into the following article.

\section{T $T$ IS A WELL KNOWN FACT that many Germans found their way into this country after the abortive revolutions of I 1848-I 849. Such men as Carl Schurz and Franz Sigel, or the family of the late Wendell Willkie, immigrated to the United States as the result of conditions in the Germanies. However, the political refugees came not only from the German states proper but also from the Austrian empire.}

Among those who arrived in the United States in the wake of the disastrous ending of the revolutions was a nineteen-year-old deserter from the imperial army of Austria. He was Franz Sales Maximillian Ignatz Aloise Schneeweiss, or Franz Schneeweiss for short, who became one of the few "48ers" to settle in New Brunswick or the county of Middlesex. Differently from many other immigrants whose troubles were by no means over when they came to the New World and tried to settle there, Schneeweiss lived for over thirty years a rather comfortable and uneventful life in New Brunswick, founding a well-established and much respected family. But differently, too, his escape from the Old World had been most dramatic and spectacular, and his means of coming here had indeed been of a most uncommon nature.

Young Schneeweiss, who had been born in Eisenerz, Styria, on January 29, I 83I, was the scion of a family which could boast at least several quarterings of nobility. His paternal grandfather was the owner of the ancient castle Arnoldstein which was ransacked by Napoleonic troops and thereafter lost to the family due to heavy 
indebtedness. The father of Franz Schneeweiss was an imperial councillor and law court official. His mother traced her family to Prussian officers, including her father Carl Lindes von Lindenau, a colonel.

Franz Schneeweiss therefore was from birth well connected and could be expected to become an officer or an official of some standing in the hierarchy of Austrian officialdom. But fate willed otherwise. Like so many other young men in his generation, Schneeweiss was caught up in the great tug-of-war between those who desired political reforms and those who denied them. After attending school and university in various locations in Styria and Carinthia, he headed for Vienna. When he arrived there on September 28, I 848, he came right into the center of the revolution which had started in the capital of the Austrian empire some six months earlier. But by September the revolution had run into increasing difficulties, and so had the revolutionaries. A powerful counter-revolutionary army under Prince Windschgrätz and Count Jellačic was about to attack Vienna and to restore it to the control of the new Emperor Francis Joseph I. Franz Schneeweiss as a law student quite naturally enlisted in the famed Academic Legion which had won so much distinction in the initial stages of the March revolution. ${ }^{1}$ According to his own account he saw action for the first time on October 6, I 848. Unfortunately, no details of the eventful days were preserved by Schneeweiss himself. But there exists an undated account written down from family tradition. A son of Franz's younger sister Amalie recorded these reminiscences in somewhat ungrammatical English.

"She [Amalie] saw her brother pale, wounded, fainted in a torn Hungarian coat. She poared [sic] some wine into his mouth, that he woke up. He then told her that he had been imprisoned because he had taken part in the fight and taken the party of the Hungarians. ${ }^{2}$ A brave comrade had helped him to be free. He would probably have been shot, if he had not got out of prison."”

This story has probably a considerable amount of truth in it, especially since the victorious counter-revolutionaries did execute a

\footnotetext{
${ }^{1}$ On the role of the Academic Legion see especially Priscilla Robertson, Revolutions of 1848: a Social History (Princeton, 1952) Chap. XI.

2 The Hungarian revolutionaries led by Ladislas Kossuth attempted to bring succour to their fellow-revolutionaries in Vienna but were driven off.

${ }^{3}$ Schneeweiss papers, folder 7. Undated memorandum drawn up by Schneeweiss' nephew, Hermann.
} 
number of the prisoners they had taken. In any event, Schneeweiss was spared this fate and retired for some time to his native Styria. But apparently he was living under a cloud and his participation in the Viennese revolution brought discrimination against him and his parents. Sometime in 1849 he saw himself compelled to enlist in the imperial Austrian army in order to clear his record. He was attached as a cadet to the $47^{\text {th }}$ infantry regiment which was stationed in Italy. Within less than a year he was so distressed and disgusted that he decided to desert.

Franz Schneeweiss' main diary contains some indication as to why he decided on this drastic step which was to end in considerable difficulties for himself as well as for his family. On Christmas eve, I 849, when his diary entries begin, he wrote of his desire to live like "a human being among other human beings." Young romantic that he apparently was, he at first tried to escape the grim realities of his life by turning to poetry and philosophy. Only very occasionally would he mention political issues, perhaps for fear that the diary might fall into unfriendly hands. He must have been under a great emotional stress that was quite natural in an adolescent, scarcely nineteen years old. In his despair he decided on desertion and prepared for it.

There are no diary entries between the last week in September I 850 and October I 9 because during this time Schneeweiss managed a daring escape together with some fellow-soldiers. On the latter day, however, he revealed some of the events that had led to his ultimate freedom. The entry for October I 9 states:

"The plan was ready. On September 29, 1850, at 6 p.m. we escaped the fetters of Austrian tyranny. We sailed the whole day toward the high seas in a rather considerable storm. Finally, we saw the lighthouse of Spezia. With fresh courage we headed for it and reached the gulf at I a.m." ${ }^{5}$

Once the deserters had reached this port in the Sardinian Kingdom from Leghorn, they had evidently succeeded in their main objective

\footnotetext{
${ }^{4}$ Schneeweiss Diary (scattered) December 24, I 849 -November 5, I 855 . Unless otherwise noted this diary is referred to here as Schneeweiss Diary.

${ }^{5}$ Schneeweiss' diary entries then continue for some time in Greek letters which he used as a cipher in the hope that it might guard essential secrets. Indeed this cipher language would have posed an almost insurmountable difficulty to the present writer had it not been for the most generous and able help of the custodian of manuscripts at Rutgers Library, Donald Sinclair. The author wishes to record here his obligations and thanks.
} 
to flee the Austrian army. However their difficulties were by no means over. They were interned for about a week in the military hospital, but with the help of the Italian commissioner in charge and some of the local population Schneeweiss and his few associates managed to leave. It was at this juncture that they were taken aboard the U.S.S. Lexington which was anchored off Spezia together with some other American ships of the Mediterranean squadron.

The Lexington was a store ship normally attached to the Brazil squadron but temporarily detailed for duty with the Mediterranean squadron. Several Hungarian deserters had already found refuge aboard her. Among them was the former adjutant of the well-known General Joseph Bem who had played a leading part in the Hungarian rising of I 848-1 849. On October 7 the arrival of the Schneeweiss group was briefly recorded in the logbook of the Lexington as follows: "Received on board four Hungarians." ${ }^{\text {"The }}$ Three days later provisions were made to accommodate all the deserters in a more permanent fashion. "Three carpenters from the Flag ship employed on board putting up berths for the Hungarians." Evidently the latter had decided on the long trip to the United States.

The admission of a number of deserters aboard a U.S. navy vessel bound for the United States was quite naturally an extraordinary step and one that required specific instructions and explanations. The former were provided by the commander of the Mediterranean squadron, Commodore Charles W. Morgan. On November 6, I 850, he instructed the captain of the Lexington, John K. Mitchell:

"The Hungarian officers who are now on board of your ship and who have received my permission to take passage in her to the United States, will be furnished with such articles from the ship's stores, as may be necessary for their comfort, but such supply will not, in any case exceed ... the ordinary allowance for one of your crew. You will permit them, upon your arrival at New York, to land, and at the earliest practicable period, report the fact of their transportation to the Honorable Secretary of the Navy, explaining to him also the circumstances which imposed upon me the necessity for deviating, in this instance, from my general rule."

${ }^{6}$ Log of United States Store Ship Lexington commanded by Lieutenant John K. Mitchell, Esq., National Archives, Washington, D.C. The term "Hungarians" was somewhat loosely used since at least Schneeweiss was of German-Austrian descent.

${ }^{7}$ Ibid.

${ }^{8}$ Navy Department, Officers letters, I $8_{5}$, National Archives, p. I28. (The numbering is that of the compilers of this volume.) 
Lieutenant Mitchell, for whom Schneeweiss felt quite an abiding affection and who in the War between the States became a ranking officer in the Confederate navy, explained the situation at length upon arrival in New York. On January I3, I85 I, he sent the following letter to the Secretary of the Navy, William A. Graham:

"I have the honor of reporting the safe return of this ship under my command ... Enclosed are ... lists of the officers attached to this ship ... and of eight Hungarian passengers received on board at Spezia.

The Hungarian passengers represent themselves as having all (with the exception of one) been officers late in the military service of their country, in the subjugation of which, they were condemned to serve for life in the ranks of the Austrian army, and that their corps having been quartered at Leghorn, they succeeded in making their escape to Spezia. By their desertion they forfeited their lives, a penalty which a number of their compatriots had already paid for the same and which awaited them if retaken... The local authorities and inhabitants of Spezia manifested an active support in behalf of the refugees and ... offered them facilities for reaching our squadron ... where they were received aboard of this ship for a passage to the U.S. . . . by order of Commander C. W. Morgan by whom I am instructed to report the fact of their transportation, etc. to the Department."

So much about the official reports concerning the escape of Franz Schneeweiss to this country. He, too, kept a logbook of a more personal nature, his diary. Apparently his first days aboard the Lexington were not altogether pleasant if judged from such entries as the following: "We lived through disagreeable days on the American vessel."

Presumably Schneeweiss was tired of waiting which is evident from the entry of October 30, I 850: "We are still in Spezia. I want to get away, far away. ..."11 Not until November 7 was his wish fulfilled when the Lexington set sail for Gibraltar, arriving there on November 26. On the way Schneeweiss had evidently not as yet decided what to do. He wavered much between returning to his native country and moving toward what must have been to him the other end of the world. But after a short stay in Gibraltar, the young deserter finally resolved to part with the Old World and turn to the new one. On December I, 1850 , he entered in his diary: "At noon we left Gibraltar and thus Europe." ${ }^{\text {"2 }}$ At the same time he penned a long farewell poem to Europe which read in part:

\footnotetext{
${ }^{9}$ Ibid., p. 1 30 .

${ }^{11}$ Ibid., p. 32.

${ }^{10}$ Schneeweiss Diary, p. I I.

${ }^{12}$ Ibid., p. 34 .
} 
And the last bond is broken

Which has tied me to this life.

Receding from the glance of the banished

Beloved fields, fare thee well;

Thou fair regions of my homeland

Fare thee well, fortune vanished.

Aboard the Lexington he wrote a long letter to his parents, a copy of which he preserved in his diary. He attempted to justify his desertion, knowing evidently that it would cause severe repercussions for them. The confused and pathetic letter read in part:

"Not on account of thoughtlessness or wantonness, striving for childish independence, did I slip off the fetters. No! . . To achieve something in the k.k. ${ }^{13}$ army, especially in Italy is beneath the dignity of man because everything is aimed to keep away from the emperor even the smallest innovation, to form the tools of crying injustice and inhumaneness and to serve as a tool of the most fanatical tyrant . . . I hope to build an untrammelled future in the far away colonies $[s i c]$. . . Perhaps I will be granted to see again my fatherland and my family; if not, do not forget that there is a loyal heart which beats for you in the other part of the world."14

The trip was rather uneventful. On December 5 Schneeweiss recorded a storm that lasted for four days. On December 25 he mentioned the death of a ship's steward who was suitably buried on the high seas. On January I, I $85 \mathrm{I}$, he made the following significant entry: "A new year begins, a new era of my life; will it be favorable? Darkness beneficially veils the future . . . I will utilize it, utilize it in every way. America, the young hemisphere, shall be the school for my life." ${ }^{15}$

Franz Schneeweiss' attitude toward the new country which he was about to enter, became gradually more positive. He apparently had made some friends among the officers of the Lexington and also the Constitution. He dedicated an acrostic to a midshipman by the name of Robert C. Duvall who served aboard the Constitution. This poem was, like so many other of his earlier poems, full of romantic pathos, but it was also sincere and spoke of the debt he and his fellow-deserters owed to Duvall and the U.S. navy in general. Early in January the Lexington encountered another storm but

${ }^{13}$ This term referred to imperial-royal authority.

14 Schneeweiss Diary, p. II.

15 Ibid., p. 37 
on the twelfth of that month land was sighted and on the following day the ship cast anchor in New York harbor. Franz Schneeweiss had reached the gateway to a new land and to a new life.

There is little known about the next few years of his life. On September 29, I $85 \mathrm{I}$, he recorded his sentiments in connection with the first anniversary of his flight from the Old World. He apparently had not altogether accepted the customs and spirit of the New World.

"Today it is a year that I fled the fetters ... which suppressed every forward move of the free-born mind. America, shall I regard you with admiration or contempt? ... You developed with equal freedom the noblest motivations and the lowest passions... One thing I do miss. Why is there no respect ... for the sciences, for the spiritual predominance of the intelligence?"16

Evidently the new arrival was startled by the practical and pragmatic attitude of so many Americans, a point of view not uncommon among the European-born then and now. Yet Schneeweiss himself found his livelihood for a year or two as a laborer, probably in a factory.

Sometime in the spring of 1852 he must have first come to New Brunswick, although there is no evidence as to what brought him there. On May 22, I852, he wrote in his diary with a note of optimism, if not jubilance: "I have entered into a new era; my dreams are about to be realized; the goal of painful effort, lasting endeavor, untiring activity, and burning desires has nearly been reached." religious conversion that was to affect his life in such a decisive manner. He apparently had come under the influence of certain Protestant clergymen and decided not only to turn to Protestantism but to become a clergyman himself. On August 23, I 852, he recorded in his diary: "A higher power has guided me. It was providence which caused me to find out about everything until I found the right thing."18

But Franz Schneeweiss was not a person free from scruples or prolonged mental struggles. A fortnight later he spoke of the difficulties in which he found himself, the absence of peace of mind, and the passions that pulled him one way or the other. Not until October
${ }^{16}$ Ibid., p. 39.
${ }^{17}$ Ibid., p. 35 .
${ }^{18}$ Ibid., p. 55 . 
I 852, and not without assistance on the part of such men as Pastor J. K. Ferris from Perth Amboy, did he take the decisive step. On October I7 he recorded this entry in his diary: "Since October I I am a theologian. Wondrous event! $\mathrm{Me}-\mathrm{a}$ theologian. The last months have brought unique changes." ${ }^{\text {"19 }}$ At the beginning of that month Franz Schneeweiss entered the theological seminary maintained in New Brunswick by the Dutch Reformed Church and up to I 864 associated with Rutgers College.

After several years of study Schneeweiss was graduated in I 855 from the seminary and became an ordained minister. In the same year he was appointed pastor of the Third Reformed Church in New Brunswick. This church was situated at Guilden Street and was established in I $85 \mathrm{I}$ largely for the benefit of the German-speaking population of New Brunswick. ${ }^{20}$ Schneeweiss delivered his first sermon on October 21, I855, and it was well received. ${ }^{21}$

At the end of three years, however, Schneeweiss left the pastorate in New Brunswick, and for some time worked as a "City Missionary" among the Germans in Brooklyn. ${ }^{22}$ After 1860 he gave up all religious work and henceforth worked as a music teacher. His heart and probably his best abilities were in the field of music, very much as in the case of his noted sister Amalie, about whom more will be said. Franz Schneeweiss became the founder and secretary of the Septemvirs, a musical association in New Brunswick. He also served as organist in several churches in the vicinity of New Brunswick. Occasionally Schneeweiss would compose a few pieces and oftentimes he would act as a choir leader. There is still preserved a musical program rendered in February I 878 in St. James's Church. Schneeweiss not only was the director of the concert but supplied three items from his own compositions.

In addition he was active in the organization of other associations. Thus he founded the Association for the Furtherance of German Sciences, for which he meticulously drew up an elaborate constitu-

${ }^{19}$ Ibid., p. 57 .

${ }^{20}$ Cf. John P. Wall, The Chronicles of New Brunswick, New Jersey (New Brunswick, 1931), p. ro7, and W. Woodford Clayton, ed., History of Union and Middlesex Counties (Philadelphia, I 882 ), p. 735 .

${ }_{21}^{21}$ Cf. The Fredonian, October 24,1855 .

${ }^{22}$ Cf. Edward Tanjore Corwin, A Manual of the Reformed Church in America. 4th edn. revised and enlarged. (New York, I 902), pp. 704-705. 
tion. The aims of this society were above all to deliver and discuss lectures of a scientific nature "with the strictest exclusion of nonChristian tendencies."23

Franz Schneeweiss did not neglect his family life, in spite of his manifold interests. On October 24, I 855, he had married Mary Parsell who came of a well-established Jersey family. The marriage was very happy and led to the founding of a prosperous and large family. There were three sons of whom Henry Parsell Schneeweiss became treasurer of Rutgers University from I9I 5 to I928; Franz Maximilian became rector of an Episcopal church, while Oliver Parsell Schneeweiss was prominent in the business world. ${ }^{24}$

While the Schneeweiss-Parsell family prospered, Franz's own family in Austria fell on evil days. His father died in 1851 due in part to the grief suffered from the desertion of his son and the professional setbacks suffered as a result of this desertion. His mother and sister moved first to Transylvania and then to Vienna. Franz's second sister Amalie, a gifted and later renowned singer, attempted to provide for the family by entering a stage career when only fourteen years old. But misfortunes fastened on the three women. At one time the cashier of the company for which Amalie played absconded with the payroll. At another time the Schneeweiss women were stuck for over a week in a remote village while somebody else took the part of Amalie, who lost her contract as a result of their delay en route.

Franz's mother was able by I 854 to establish communication with her son from whom she had not heard for over six years. From Hermannstadt she wrote on June 30,1854 , in a letter such as any mother whose son had suddenly disappeared might have written:

"My dear Son:

Why have you done this to me! But a mother is only concerned with the genuine happiness of her child, and if you are happy I will gladly forget all the pain and grief which your disappearance have caused me. Dear Franz, above all please write soon how and where you live, whether you are satisfied, and what has happened to you."25

${ }^{23} \mathrm{Cf}$. Schneeweiss papers, folder 8.

${ }^{24}$ Cf. Carl H. Gramm, The Germans in New Brunswick, N.J. (Cleveland, I938), p. 4I, and folders on Henry Parsell and Oliver Parsell Schneeweiss in possession of Rutgers Library.

${ }^{25}$ Schneeweiss papers, folder I. 
The correspondence thus initiated was of a somewhat spasmodic character since Franz Schneeweiss did not reply as regularly as his mother expected. From Vienna, where she had moved, Mother Schneeweiss, as she signed her many letters, wrote repeatedly to Franz. The conditions in which the three women found themselves prompted various moving letters from Franz's mother, Eleonora Katherina, pleading with her son to support the family left behind. Some support was forthcoming but not enough to pay back the heavy debts incurred. Even while she lay dying of the cholera in I 855 Katherina Schneeweiss appealed to Franz and his wife Mary not to leave her daughters unprotected. The moving note which she attempted to pen a few hours before her death speaks for itself and for the woman whose last thoughts were her children: "Dear Franz and Mary, I bless you on my death bed and plead with you not to leave my children." ${ }^{26}$

But the Schneeweiss sisters remained hard pressed by their debts and creditors. Franz, who suggested that they join him in the United States, was rebuffed because his sisters did not wish to take "a French leave." To make matters worse still his older sister, Minna, suffered from tuberculosis of which she died in 1856 . His other sister, Amalie, who was extremely gifted and quite a personality, managed finally to get her head above water. In I 863 she secured an engagement as contralto singer at the royal opera of Hanover.

There she met the violin virtuoso and conductor Joseph Joachim whom she married in June, I 863. As a biographer remarked: "The union of these two great artists had a great influence on the art of their time; their house was a centre of the truest musical culture."27 Unfortunately, the marriage broke up in I $88 \mathrm{I}$ after six children had been born. Amalie, better known as Maly, appealed to her brother earlier in that year to come at once to Berlin since she had nobody else to take her side. Franz Schneeweiss responded and took his second trip back to Europe.

In $187^{2}$ he had for the first time returned to the Old World. At that time his travels were mainly caused by sentiment and Heimweh.

${ }^{26}$ Ibid.

${ }^{27}$ J. A. Fuller-Maitland, Joseph Joachim (London, I905), p. I4. Joachim was Felix Mendelssohn's protegé. He rose in quick succession from concertmaster at the ducal court of Saxe-Weimar to conductor of the opera at Hanover, and ultimately became professor of music at the Royal Academy of Arts in Berlin. 
In order to return to his native Austria he had invoked an imperial pardon. The draft for his pardon is among his papers. Not only did he appeal to the emperor, Francis Joseph, but he also wrote to the foreign minister, Count Julius Andrassy. In this letter he wrote: "For twenty years an American citizen I enjoy a good and safe position. ... The only motive to plead for imperial clemency is the desire to atone for the wrong committed in my youth ... and to see temporarily once more [my native country]."28 At the same time Franz Schneeweiss pointed out that he had never taken an oath of allegiance as a soldier of the emperor since he was by chance called away from the swearing-in ceremony.

Schneeweiss also enlisted the support of influential United States officials including Senator F. T. Frelinghuysen, then Senator from New Jersey; Senator Simon Cameron, then Chairman of the Foreign Relations Committee; the second Assistant Secretary of State, William Hunter, and John Jay who was the U.S. Ambassador to Vienna. All these men interested themselves in the plea for a pardon. On January 24, I 873, Ambassador Jay wrote to Schneeweiss as follows: "I have addressed a note in your behalf to the Count Andrassy ... As His Excellency was himself an exile for many years for the part he took in Hungary, I have little doubt of a favorable response."29

A month later the United States Ambassador to Vienna forwarded a further communication to Franz Schneeweiss. In it he stated that information had just reached him that Schneeweiss was included in a general imperial pardon. This pardon had been granted as a result of a treaty between Italy and Austria in 1866 . However, the pardon reached Schneeweiss too late to enable him to travel to Austria since he had returned from Europe in the previous year. During his extended tour he had gone to Britain, the Netherlands, Switzerland, and Germany. In the latter country he had seen his sister Amalie and her husband and spent some time with his relatives.

When he went back in I 88I it was in order to help his sister in the divorce proceedings started by Joseph Joachim. While he was not able to hinder these, he convinced himself of Maly's guiltlessness.

${ }^{28}$ Schneeweiss papers, folder 2.

${ }^{29}$ Ibid. 
In the words of a disinterested third party the reason for ultimate divorce was "perhaps nothing worse than his [Joachim's] intense jealousy." ${ }^{30}$ In any event the rift between the two noted artists was not so final as to hinder a moving, ultimate conciliation. When Amalie lay dying in February I 899, Joseph Joachim hastened to her bedside. But for more than fifteen years the separation lasted.

During this time Amalie Weiss, as she was known in the world of musicians, lived by herself and made several reappearances on the stage. When she came to the United States in 1892 for a concert tour, her brother had been dead for four years. His life in his later years had apparently been quite uneventful. In politics he was a Republican as so many other Germans and German-Austrians who came to this country in mid-century and afterwards. Yet Franz Schneeweiss never played any substantial part in either local or national politics.

When he died in the spring of I 888 Schneeweiss was a respected citizen of New Brunswick, but there is no evidence that he had become in any way prominent outside this city. An obituary reads:

"He was well known in town, having lived here for many years . . Many years ago he preached in a little church . . . but afterwards took up his profession of a music teacher, and many of our citizens have profited by his thorough training... He had many friends in this city who will hear with regret of his death. ${ }^{31}$

Thus ended after fifty-seven years the life of Franz Schneeweiss. As in the case of so many other immigrants, he came from a continent and era much troubled. But also like so many immigrants he found a haven in this country and settled down to an undisturbed and successful, although modest and quiet life. Those who had been branded as revolutionaries in Europe or had wrested themselves loose from the fetters of tyranny became generally good citizens of this country. Franz Schneeweiss, as so many who came before, with, and after him, set a lasting example of how countless refugees have well adapted themselves to the life of this Republic and added new strength and dedication to it.

\footnotetext{
${ }^{30}$ Statement made in biographical article on Joseph Joachim in Grove's Dictionary of Music and Musicians, 5 th edn. (London, 1954), IV, 643. The same article points out that Johannes Brahms himself took the side of Amalie and actually broke with Joachim over the divorce issue.

${ }^{31}$ New Brunswick Daily Times, May 16, I 888.
} 